\title{
Commentary
}

\section{Indigenous Peoples and the Australian \\ census: value, trust, and participation}

\author{
Bhiamie Williamson* (Euahlayi) The Australian National University \\ Jacob Prehn (Worimi) University of Tasmania \\ Maggie Walter (Palawa) University of Tasmania \\ Raymond Lovett (Wongaibon, Ngiyampaa) The Australian National University; Australian Institute \\ of Aboriginal and Torres Strait Islander Studies \\ Gawaian Bodkin-Andrews (D’harawal) University of Technology, Sydney \\ Bobby Maher (Yamatji) The Australian National University \\ Vanessa Lee-Ah Mat (Yupungathi, Meriam) University of Sydney \\ Roxanne Jones (Palawa) The Australian National University \\ * Corresponding author. Email: bhiamie.williamson@anu.edu.au. Address: Centre for Aboriginal \\ Economic Policy Research (CAEPR), Copland Building \#24, The Australian National University, Acton, \\ ACT, 2601, Australia.
}

Paper received 21 February 2021; accepted 14 September 2021; published 29 November 2021

\section{Introduction}

Reliable population data are foundational to the functioning of nations. Population data are important for making and informing decisions about national policy parameters and supporting resource allocation (Lovett 2016). The Australian five yearly census of Population and Housing (the census) is critical in the production of this information and as such, has become a feature in Australia's social and political landscape. The census also provides the data for a national narrative including who or what Australia is and how it is changing over time (through categorisation and data compilation). As Māori scholar Kukutai (2011 p. 33) states, the Aotearoa (New Zealand) census, similar to the Australian census, is "an influential site of inclusion and exclusion where the state selectively acknowledges collective identities". Yet in Australia, the census has a complicated and difficult history in relation to Aboriginal and Torres Strait Islander (henceforth referred to as Indigenous) peoples. Because while the Australian Bureau of Statistics (ABS) asserts that the purpose of the census is "to measure the number and key characteristics of persons and dwellings in Australia" (ABS 2017), for most of its history the tabulated number of persons did not include Indigenous individuals ${ }^{1}$ (Markham \& Biddle 2018). Similarly, while the motives for the census are stated as "for electoral purposes; and to support activities of governments, business, and other users" Indigenous peoples have rarely, if ever, been considered as being among legitimate 'users' of census data (Walter, 2016). This complicated history and neglect of the unique data needs of Indigenous peoples has resulted in a sustained undercount of Indigenous peoples in the census (Andrews 2018; Markham \& Biddle 2018; Taylor \& Biddle 2010). It is

\footnotetext{
${ }^{1}$ We note that previous to 1971 , censuses did count Indigenous individuals but for the purposes of removing them from official estimates.
} 
time that these issues are named, and paths forward explored; a necessary step to better reflect the needs and ambitions of Indigenous peoples, while simultaneously addressing the entrenched issue of Indigenous participation, or lack thereof, in the census.

In this commentary we, as a group of Indigenous academics, trace the relationship between the Australian census and Indigenous peoples, addressing historical and present dimensions through the dual lens of value and trust. Although we come from various disciplines including statistics, public health, social science, and human geography, our approach and analysis is firmly rooted in, and builds upon, postcolonial demography that Kukutai \& Taylor (2012 p. 14) state, "highlights the epistemological and methodological shortcomings of applied demographic research on Indigenous peoples, and generates calls for more innovative approaches."

Firstly, we examine engagements between Indigenous peoples and the census. We then discuss the central issue of the value, or lack of value, which census data provides for Indigenous communities, and Nations, before highlighting the lack of trust Indigenous peoples have in government processes such as the census. We argue that the current Indigenous 'origin' question should be redesigned and draw on examples from other English-speaking settler-colonial nations to support alternates. We finish by drawing attention to Indigenous Data Sovereignty and Indigenous Data Governance and propose that redesigning the census question is equally, if not more so, a question of process and structure as well as the wording of specific census questions.

\section{Indigenous Peoples and the census}

When the first Australian census was conducted in 1911, those Indigenous people who were classified as 'natives' were deliberately and officially absented from the population count (Kukutai \& Walter 2015; Rowse \& Smith 2010; Yu 2012) with Section 127 of the Australian Constitution stating: 'In reckoning the numbers of the people of the Commonwealth, of a State or other part of the Commonwealth, Aboriginal natives shall not be counted' (United Kingdom House of Commons 1900). The lack of debate at Constitutional Conventions surrounding this exclusion suggests a shared understanding at the time that Indigenous peoples were a 'dying race' and that they would have no role or place in the future of Australia (Chesterman \& Galligan 1997).

Section 127 of the Australian Constitution was repealed by the 1967 referendum and in 1971, the 'race' question was modified to ask 'What is the person's racial origin?', with tick boxes provided for 'European origin', 'Aboriginal origin' or 'Torres Strait Islander origin' (ABS 1971). But the question of Indigenous identity has evolved and changed since.

In 1978, National Cabinet (ABS 2014) adopted the 'three-part' definition of Indigenous identity. This was then formalised in the 1980s through the Aboriginal Affairs' Report on a Review of the Administration of the Working Definition of Aboriginal and Torres Strait Islanders that stated:

An Aboriginal or Torres Strait Islander is a person of Aboriginal or Torres Strait Islander descent who identifies as an Aboriginal or Torres Strait Islander and is accepted as such by the community in which he or she lives (Department of Parliamentary Library 2003). 
The three-part definition then continued to be adopted across Commonwealth, State, and Territory government departments as a mechanism for eligibility and access to targeted services for Aboriginal and Torres Strait Islander peoples (Department of Parliamentary Library 2003).

In subsequent censuses the wording of this question has varied slightly until 1996 when it was replaced with the current question: Are you of Aboriginal or Torres Strait Islander origin? Options respondents are provided with include: (i) No; (ii) Yes, Aboriginal; and (iii) Yes, Torres Strait Islander, with respondents prompted so that persons of both Aboriginal and Torres Strait Islander origin, [should] mark both 'Yes' boxes² (Markham \& Biddle 2018).

The ABS states that the:

Standard Indigenous Question is based upon the Commonwealth working definition but does not include the third element of the Commonwealth definition, namely that 'an Aboriginal or Torres Strait Islander is a person who is accepted as such by the community in which he or she lives' (ABS 2014).

Despite the development and widespread adoption of the three-part definition that demonstrates origin is but one part of a more complex identity, the Indigenous identifier question in the census continues to clearly be framed solely in terms of 'descent' or 'origin'. And whilst the ABS explicitly acknowledges that the Indigenous identifier does not include the third element of community affiliation, we argue that it also does not include the second element, namely that for a person to be Indigenous they must identify as such, providing justification later in this paper.

Inclusion in the national census has also brought with it problems relating to the enumeration of Indigenous populations. Key among these is the significant and consistent Indigenous undercount (Andrews 2018; Markham \& Biddle 2018; Taylor \& Biddle 2010). 'Undercount' refers to both the incorrect compiling of data, and/or the non-completion of the Indigenous identifier question, to suggest fewer Indigenous people than there actually are. That the census fails to accurately capture Indigenous populations compromises the "purpose of the census and what it aims to do" (Andrews 2018 p. 45). The reasons given for this consistent undercount vary, but can include historical exclusions (e.g., racism), lack of trust, or relevance of questions asked. To be clear, we do not wish to diminish the efforts to enumerate Indigenous populations, especially where Indigenous peoples themselves have been engaged in the processes to design the Indigenous identifier question. Rather, we suggest that an evolution of the Indigenous identifier question would create greater value than is currently being generated, and thus would create the conditions for more substantial engagement.

But creating more value in data through a redesigned census question may be insufficient in-and-ofitself. There remain serious issues of accessibility (understanding what the census is, and how and when to complete) and availability (some Indigenous communities are difficult to reach due to remoteness, varying levels of literacy, and lack of access to services) (Jelfs 2016; Markham \& Biddle 2018; Walter 2010). The ABS, as the agency tasked with conducting the census, aimed to address accessibility and availability issues using methods such as: specific targeting of Indigenous peoples;

\footnotetext{
${ }^{2}$ The 2016 Census questionnaire can be viewed in full at https://www.abs.gov.au/ausstats/abs@.nsf/Lookup/2901.0Main\%20Features802016/\$FILE/2016\%20Census\% 20Sample\%20Household\%20Form.pdf
} 
the employment of Indigenous Engagement Officers; training (including cultural safe practice) and employment of interviewers in remote Indigenous communities; and the establishment of an Indigenous Statistics Centre (Jelfs 2016), although much more can and should be done to appropriately engage Indigenous peoples (Brackertz 2007). However, the more complex issue of deliberate non-participation by Indigenous peoples remains unresolved.

The exact number of Indigenous peoples choosing not to participate in the census is almost impossible to measure. On the basis of the ABS post-enumeration survey, where about 50,000 households are approached several weeks after the census in a face-to-face setting, the ABS estimates an Indigenous undercount of at least 10\% since 2001 (Markham \& Biddle 2018) and up to 17.2\% in 2011 and 17.5\% in 2016 (ABS 2017). However, official estimates of the Indigenous undercount are likely to be conservative, as they assume that people correctly identify their Indigenous ancestry to an ABS Indigenous or non-Indigenous interviewer.

This non-participation is largely driven by a perception from Indigenous peoples that the census is of little relevance and value (Andrews 2018; Yap \& Yu 2016). The emergence of such perceptions is easy to understand. Whilst amending the deliberate exclusion of Indigenous people from the census corrected a particular historical wrong, it is currently little more than a tick-a-box exercise that does little to recognise and progress the complex identities, voices, needs, and aspirations of Indigenous peoples and communities (Andrews 2018; Crooks et al. 2019; Kukutai \& Walter 2015; Taylor 2009; Yap \& Yu 2016). As Altman and Taylor (1996 p. 193) state, the current census question and the data derived from it are merely the "by-product of including an Indigenous identifier". Kukutai and Taylor go further, pointing out that:

a significant irony is emerging that, at a time when we see an unprecedented volume and range of data on something called the "Indigenous population"... there remains a dearth of information on the various socio/cultural entities that make up those populations (Kukutai and Taylor 2012 p. 18).

The census, as a key source of Indigenous data without an aligned purpose of meeting Indigenous needs, has two main problems; what we call the Indigenous data paradox. First, as argued by Walter (2016 p. 80), current Indigenous data production and analysis tends to be focused around the 'five Ds' of data. These are: disparity; deprivation; disadvantage; dysfunction; and difference. Always pejoratively compared to the non-Indigenous population, data contributes to a persistent national data narrative that sees Indigenous peoples as the problem. The other side of the paradox is the lack of data value to Indigenous 'users', that is Indigenous peoples, populations, communities, and First Nations. As stated by Yu (2012), current census output does not support the requirements of Indigenous collectives to plan for their people's current or future needs. The long history of surveillance of, and discrimination against, Indigenous peoples by Australian governments complicates this even further. What is clear is that unlike mainstream Australia whose participation in the census is seen as an extension of their civic duty, not unlike voting, the census is not apolitical. Rather, for Indigenous peoples, choosing to participate or not is a profoundly political act (Andrews 2018). 


\section{On value and on trust}

Globally, colonised Indigenous peoples still largely retain and organise around their own social, cultural, and political groups (Alfred \& Corntassel 2005; Anderson et al. 2016; Hemming et al. 2019). These groups exist with their own governance systems, legal arrangements, citizenship requirements, and land and water management practices (Alfred \& Corntassel 2005; Hemming et al. 2019). Prior to colonisation, these distinct Indigenous peoples had well-developed processes for recording, producing, controlling, and interpreting their own data ${ }^{3}$ (CBC Radio 2017; Pool 2016). These data were a strategic asset that groups could use to make informed decisions and plan for the future of their peoples and management of their lands and waters.

Today, the vastly different, unique, and complex societies of First Peoples who have lived on the Australian continent are collectively known as 'Indigenous' and other allied terms (for example: Aboriginal, Torres Strait Islander, and First Nations) (Peters \& Mika 2017). Although these descriptors are deployed to refer to the first peoples of the Australian continent, none of these terms are themselves Indigenous (Peters \& Mika 2017). Rather, they are constructs of Western thought that has aimed to name and define different peoples throughout the 'New World' in relation to European colonisers (Peters \& Mika 2017; Veracini 2011; Wolfe 1999). Notwithstanding that there may be instances where Indigenous peoples choose to participate in this Western discourse, such as adopting the term 'Indigenous' in the United Nations to pursue common goals ${ }^{4}$, many Indigenous polities continue to identify and organise around their own naming conventions (Peters \& Mika 2017; Smith 2013; Sutton 2003).

The now centuries-long suppression of Indigenous languages has caused degradation, fragmentation, and in some areas, almost complete eradication of Indigenous peoples' languages (Attwood \& Markus 1999). The suppression of Indigenous ways of being, knowing, and doing further degrades Indigenous identity and belonging (Alfred \& Corntassel 2005; Martin \& Mirraboopa 2003; Wolfe 1999). Yet despite these deeply colonial practices, Indigenous peoples' ways of being, knowing, and doing including languages and naming conventions, have both survived and continue to be revived (Alfred \& Corntassel 2005). One of the first observable naming conventions shared by Indigenous peoples throughout the world is the naming of their group(s) or nation(s) (Peters \& Mika 2017). Identifying with specific language groups or nations is emblematic of Indigenous ways of being, knowing, and doing (Alfred \& Corntassel 2005; Martin \& Mirraboopa 2003) but there are added elements of this worldview that are of importance when considering Indigenous-specific census questions.

The current census question raises concerns because, as we outlined earlier, of its continued emphasis on origin rather than identification (Crooks et al. 2019). Yes, knowing the total number of people whose origin is Aboriginal and/or Torres Strait Islander is important, but it is incomplete in its lack of reference to Indigenous communities, nations, and language groups. This framing of being Indigenous, as simply being a descendent of an Indigenous person or peoples, also does not accord

\footnotetext{
${ }^{3}$ Data refers to information or knowledge, in any format or medium, which is about and may affect Indigenous peoples both collectively and individually. See Maiam nayri Wingara \& Australian Indigenous Governance Institute (2018).

${ }^{4}$ See for example the United Nations Permanent Forum on Indigenous Issues, and the United Nations Declaration on the Rights of Indigenous Peoples (UNDRIP) (United Nations 2008).
} 
with citizenship and membership conventions of Indigenous communities (Crooks et al. 2019). Put simply, being of origin in-and-of-itself, whilst necessary, is insufficient (Crooks et al. 2019). And whilst the ABS suggests that the current Indigenous identifier question does account for identification, positing a question around the concept of origin is clearly a matter of fact, not of choice. Rather, a more accurate question would reflect the agency of individuals to identify as an Indigenous person. Crooks et al. (2019) considered the census question with its emphasis on origin against a question on FluTracking, a national system for tracking influenza-like illness, which emphasised identity. Crooks et al. (2019 p. 2) highlighted that "the origin question was a materially different question to that of identity" and found that "Aboriginal stakeholders preferred a question that omitted the concept of origin, and focussed on cultural identity; 'Are you an Aboriginal or Torres Strait Islander person?'”

In this way we agree with the conclusions drawn by Crooks et al., and argue that amending the census question from one focusing on origin to identity would be more reflective of the realities and ambitions of Indigenous peoples today (Crooks et al. 2019). A focus on identity would also more closely align the census with the 'three-part definition' of Indigeneity ${ }^{5}$, which requires ancestry, identification and community recognition ${ }^{6}$.

Indeed, for many Indigenous peoples, citizenship of their language group or nation are more culturally meaningful than being 'Australian'. The recent High Court decision in Love v Commonwealth of Australia (2020) found that an Indigenous person of Australia who is known and accepted by his, her, or their Indigenous group, cannot be considered 'Alien' under the Constitution. This High Court decision instructs us that for Indigenous peoples, issues of citizenship and group membership carry potentially far-reaching legal consequences. The current census question regarding Indigenous origin erases these identities under the colonial category of 'Indigeneity'. A realignment of the census question is needed if the census is to accurately reflect the extant social organisation and observe Indigenous peoples' right to freely determine their own identities (Anderson 2008; Kukutai \& Cormack 2020; Yap \& Yu 2016).

There also remain serious issues of trust between Indigenous peoples and Australian governments (Andrews 2018). This lack of trust stems from the long history of oppressive settler-Indigenous relations. Woiwurrung and Yorta Yorta woman and academic Dr Julie Andrews (2018) investigated census participation in Naarm (Melbourne) through a qualitative study of twenty Indigenous people. She found that the census triggered traumatic encounters between participants (including family members) and governments. One participant commented that some Aboriginal people who are in public housing do not participate in the census for fear of being evicted for having too many people in their houses:

A lot of our people are very frightened of telling the census how many people lived in their house because if they were in public housing you're only allowed to have four people and they might have eight because relatives will come and stay, so you can lose your house so they'll lie to the census (Andrews 2018 p. 45).

\footnotetext{
${ }^{5}$ For a critical discussion of the three-part definition, see Whittaker (2017).

${ }^{6}$ The three-part definition has increasingly come into use through regulation, policy and statutes and continues to be used by governments, organisations, educational institutions, and local Indigenous communities, see Whittaker (2017).
} 
There were other notable encounters that participants highlighted when discussing their nonparticipation. Key among these was the forcible removal of Indigenous children from their families and communities. As Andrews (2018 p. 49) states:

Several people interviewed shared a common history over the past 40 years - being forcibly removed from their families when they were children.... Many of these people appear to have pledged never to participate in any government information-gathering process.

Whatever the specific reason for non-participation in the census, what is clear is that many Indigenous people are suspicious of the census, with many viewing it as another government surveillance tool (Andrews 2018; Walter 2016). The lack of government engagement with Indigenous peoples about the census would indicate that these suspicions will not abate quickly (Andrews 2018). It is clear that new arrangements are needed. It is our position that these new arrangements embed Indigenous Data Sovereignty and Indigenous Data Governance to ensure they respond to the trust deficit engendered by governments' historical and on-going use of data not aligned with the interests of Indigenous peoples.

\section{Time for an Indigenous identity census question(s)?}

We believe that addressing the twin deficits of value and trust may begin by reformulation of the census questions relating to Indigeneity. Reference to similar questions in other English-speaking settler-colonial nations provides an indication of the shortcomings of the current Australian census question. The current Australian Indigenous identifier question is simplistic when compared to the question sets that apply in nations such as the United States (US) and Aotearoa (New Zealand). For example, the US 2020 asked a series of questions beginning with 'What is the person's race?' (US Census Bureau 2020). Responses include: White; Black or African American; American Indian or Alaska Native; Chinese; Filipino; Asian Indian; Vietnamese; Korean; Japanese; other Asian; Native Hawaiian; Samoan; Chamorro; Other Pacific Islander; or Some Other Race (US Census Bureau 2020). This is followed by the subsequent question: 'If American Indian and Alaska Native, print the name of the enrolled or principal tribe' (US Census Bureau 2020). The response space is left blank to be filled in by the respondent.

Similarly, In Aotearoa (New Zealand), the following series of questions is asked in relation to the person's ethnicity. First, they are asked 'To what ethnic group does the person belong to?' Responses are: New Zealand European; Maori; Samoan; Cook Island Maori; Tongan; Niuean Chinese; Indian; or Other (Statistics New Zealand 2018). Importantly, respondents can tick as many ethnic groups as they choose. There is then a specific question about descent, which asks: 'Are you descended from Maori (that is, did you have a Maori birth parent, grandparent or great-grandparent etc)?' Responses are: Yes; No; and Don't know (Statistics New Zealand 2018). Respondents are then directed to a further two questions on Iwi affiliation. The first question asks: 'Do you know the name(s) of your Iwi (tribe or tribes)?'; Responses here are: Yes; or No. Respondents are then asked to enter the name(s) and regions of up to five Iwi (Statistics New Zealand 2018). These examples clearly dismiss ABS assertion's that 'Collecting information on the basis of community acceptance is often impractical in a survey or administrative data collection setting and can lead to inaccuracies' (ABS 2014). 
We ask that governments, agencies, and organisations consider what could be gained for Indigenous peoples, our communities, First Nations, and Australia as a whole, if the focus was switched from origin to identity, asking perhaps:

\section{Do you identify as an Aboriginal and/or a Torres Strait Islander person?}

Critically, this question would need to be accompanied by further identity related questions. These could be:

Do you identify with an Aboriginal or Torres Strait Islander First Nation?; and/or;

\section{Do you identify with an Aboriginal or Torres Strait Islander language group?}

Respondents must then be given the opportunity to list their affiliations should they answer yes. Such data would allow, for the first time, the beginnings of systematic quantification of the size, composition, and other features of First Nations. As per the overall purpose of the census, such population data would, in the hands of First Nations, Indigenous organisations, and communities, support systems of governance to assess population wellbeing, set appropriate policy parameters, and support effective resource allocation for First Nations peoples and communities. We acknowledge that such an evolution of the Indigenous identifier question would be complex, but Indigenous identity is complex. Indeed, the question of identity in settler-colonial nations has been the subject of significant examination by Indigenous academics such as Carlson (2017), Heiss (2018), and internationally by Garroutte (2003) to name but a few. The reductive framing of the current Indigenous identifier question in the census fails to engage with these complex realities, or the inherent rights of Indigenous peoples to freely determine their own identities and express these identities in national forums such as the census (Anderson 2008). Many nations with identifiable Indigenous populations recognise this, with a clear trend emerging of the declining use of 'racial', and an increase in 'ethnicity', classifications (Mullane-Ronaki 2017).

Furthermore, data derived from First Nations, language, or community affiliations would have wide utility for Indigenous peoples and organisations such as native title Prescribed Bodies Corporate (PBCs) and community-controlled health organisations, among many others (Yap \& Yu 2016). As Taylor states:

the challenge for social science and for public debate is to move beyond conventional classification and recognise more ethnographically informed geographies of Indigenous peoples that are reflective of the demand for customised statistics now being expressed by representative groups (Taylor 2011 p. 13) ${ }^{7}$.

Indeed, some First Nations organisations have gone to extraordinary lengths to produce such data themselves. The Yawuru Indigenous Population Survey of Broome in 2011, for example, sought to enumerate all Indigenous residents of Broome and establish their language group affiliation to enable for better community planning (Taylor et al. 2014). The Yawuru Native Title Holders Aboriginal Corporation, through its company Nyamba Buru Yawuru (NBY), undertook this survey to

\footnotetext{
${ }^{7}$ Taylor (2012 p. 13) goes on to name groups that have expressed this view including Anindilyakwa Land Council, Thamarrurr Incorporated, Fitzroy Futures Forum, Nyamba Buru Yawuru Ltd, Mirriuwung-Gajerong Corporation and the Murray Lower Darling Rivers Indigenous Nations.
} 
"help them to "know" their own community and to engage in strategic decision-making in a postnative title determination environment' (Taylor et al. 2014 p. 14; Yap \& Yu 2016). However, such a survey required a significant investment of resources from NBY and the Commonwealth government and its expense and technical difficulty has meant that this approach has rarely been replicated elsewhere. There is therefore, a potential role for the census in collecting these data, which would significantly increase the value of the census for Indigenous peoples.

But there is also potential for harm to be caused by asking specifically about group affiliations. The legacies of colonisation and in particular, the forced removal of Indigenous children from their families and communities, has meant that many Indigenous people have been disconnected from their Country, language, and First Nation group. Asking about group affiliation when it is not known carries risk of re-exposing people who live with the trauma of separation. Conversely, it may also be a useful proxy in identifying settler-colonial process impacting on identity such as knowing how many people live with the trauma of separation (Carlson 2016).

With such complex and interconnected issues, the real question here is whether Indigenous peoples can trust Australian governments. Issues of trust apply to both the data derived from asking questions about group affiliation, as well as the processes for stewarding and safeguarding such data. There is, which has been documented here and elsewhere (see Lovett 2016; Walter 2016; Yap \& Yu 2016), a long history of data being weaponised against Indigenous peoples as an instrument of maintaining marginalisation and pejorative stereotypes (Kukutai \& Walter 2015; Yap \& Yu 2016). Data that provides information on Indigenous identity and affiliations could also be used in this way. The continuing lack of Indigenous peoples in leadership within the ABS heightens the potential for misuse, whether intentional or not.

Building trust is therefore not just a matter of the ABS declaring good intentions, of meeting with Indigenous advisory groups or holding community consultations. Rather, achieving an actual change in the relationship requires a paradigm shift on how Indigenous data are conceptualised. Such a shift requires a re-ordering of power in the data ecosystem, prioritising for the first time, the data interests of Indigenous peoples across multiple levels and across the varied processes and practices of Australian governments. Most critically, this shift must be driven by Indigenous peoples for Indigenous peoples, developing and enriching reciprocal relationships between Indigenous peoples and governments to produce systems of data stewardship built on Indigenous values and priorities and done in such a way that instils trust (Walter et al. 2020). These lessons are not only limited to the specific process that is the census, but it also applies to all government agencies that collect administrative data about Indigenous peoples including Medicare, Centrelink, health, taxation, and education. Indigenous data sovereignty and its activation mechanism, Indigenous data governance, can provide the framework of such an Indigenous data paradigm shift.

As now documented extensively, Indigenous data sovereignty is a global movement that can be broadly understood as the ability for Indigenous peoples to own, control, access, and possess their data (First Nations Information Governance Centre 2014; Walter 2018). It is a movement which has developed in response to the exclusion of Indigenous peoples from data production, analysis, and participation in the wider data ecosystem (Kukutai \& Taylor 2016; Walter et al. 2020). In practice, Indigenous data governance translates to Indigenous oversight and decision-making in relation to Indigenous data production. 
While this might require a paradigm shift to contextualise understanding by government agencies and non-Indigenous peoples more generally, many of the technical tools to accomplish Indigenous data governance already exist. To return to the example of language group or First Nations affiliations in the census, the answers to such questions could be quarantined securely by the ABS, and only released to third-parties, including other government agencies, under strict conditions. These conditions might include appropriate data access agreements signed with duly authorised representatives of that language group or First Nation. While this approach to Indigenous data governance might be novel in terms of Indigenous-settler relations, it is already routinely adopted by the ABS with respect to other sensitive data collections such as the Multi-Agency Data Integration Project (MADIP). Inspiration for such an evolution can also be drawn from Aotearoa (New Zealand) where Statistics New Zealand (2021) have a formal agreement with the Data Iwi Leaders Group, the Mana Ōrite Relationship Agreement, that seeks to 'realise the potential of data to make a sustainable, positive difference to outcomes for iwi, hapū and whānau'.

If Indigenous data governance processes are in place, such as those in the Mana Ōrite Relationship Agreement, then changing the Indigenous question in the census would lead to the creation of data that has greater value for Indigenous peoples. Specifically, in planning for their own community needs and making representations to governments and others such as NGOs and private sector interests. To be clear, we do not suggest that amending the census question in the way we propose, can or will address the decades of harm caused by five $D$ data and government statistical surveillance, we merely argue that it is an important and necessary step to create an official statistics system that meets the needs and desires of Indigenous peoples. Indigenous data governance would then enable trust building to be established in the census process by those to whom such data relates viz. Indigenous peoples, our families, communities, organisations, and First Nations (Lovett et al. 2020).

\section{Conclusion}

The ability for Indigenous peoples to identify in their own ways builds power and legitimises (in a Western legal sense) people's identities (Carlson 2016). It affirms Indigenous ways of being, knowing, and doing, and engages with the lived realities of Indigenous peoples today, thus creating value (Crooks et al. 2019). It also provides critical information, not quantified since colonisation, of group membership, demography, and mobility. However, simply changing the question may in-and-of-itself be insufficient to increase Indigenous participation in the census. There remain serious issues of trust between Indigenous peoples and the Australian nation state (Andrews 2018).

Indigenous data sovereignty enacted through Indigenous data governance provides the intellectual thought and practical blueprint to move beyond these historical legacies and promote a more equitable and just future for our communities. In this way, Indigenous peoples including our language groups, communities, and First Nations can be empowered through the provision of data about our own peoples. Such data would provide a basis to build more prosperous futures on our own terms through enhanced decision making and it would establish the foundation for a legitimate and valued place in the future of Australia. 


\section{Acknowledgments}

The authors would like to acknowledge and thank Dr Francis Markham and Professor John Taylor for their thoughtful contributions and editorial suggestions in the development of this paper.

\section{References}

ABS (1971) Census of Population and Housing, 1971. https://www.abs.gov.au/AUSSTATS/abs@.nsf/Lookup/2105.0Main+Features11971?OpenDocum ent

ABS (2014) Indigenous Status Standard. https://www.abs.gov.au/statistics/standards/indigenous-statusstandard/latest-release

ABS (2017) Census of Population and Housing: Details of Overcount and Undercount, Australia, 2016. https://www.abs.gov.au/ausstats/abs@.nsf/Lookup/by\%20Subject/2940.0 2016 Main\%20Featu res $\sim$ Indigenous\%20Status 16

ABS (2017) Census of Population and Housing: Understanding the Census and Census data, Australia, 2016. https://www.abs.gov.au/ausstats/abs@.nsf/Lookup/2900.0main+features42016

ABS (2020) Aboriginal and Torres Strait Islander Peoples. https://www.abs.gov.au/statistics/people/aboriginal-and-torres-strait-islander-peoples

Alfred T \& Corntassel J (2005) Being Indigenous: Resurgences against contemporary colonialism. Government and Opposition 40(4): 597-614.

Altman J C \& Taylor J (eds.) (1996) The 1994 National Aboriginal and Torres Strait Islander Survey: Findings and Future Prospects. Canberra: Centre for Aboriginal Economic Policy Research, Australian National University. https://caepr.cass.anu.edu.au/sites/default/files/docs/CAEPR Mono11 2.pdf

Andersen C (2008) From nation to population: the racialisation of 'Métis' in the Canadian census. Nations and Nationalism 14(2): 347-368.

Anderson I, Robson B, Connolly M, Al-Yaman F, Bjertness E, King A, Tynan M, Madden R, Bang A, Coimbra C E A, et al. (2016). Indigenous and tribal peoples' health (The Lancet-Lowitja Institute Global Collaboration): A population study. The Lancet, 388(10040): 131-157. https://doi.org/10.1016/S0140-6736(16)00345-7

Andrews J (2018) Blaks and stats in Aboriginal Victoria: Census resistance and participation. Australian Aboriginal Studies, (1), 43-56.

Attwood B \& Markus A (1999) The Struggle for Aboriginal Rights. Sydney: Allen \& Unwin.

Brackertz N (2007) Who is hard to reach and why? ISR Working Paper, Swinburne Institute for Social Research. https://library.bsl.org.au/jspui/bitstream/1/875/1/Whois htr.pdf

Carlson B (2016) The Politics of Identity. Canberra: Aboriginal Studies Press.

CBC Radio (2017) Harvard undergrad cracks code of knotted Inca rope used as "an ancient Excel spreadsheet." https://www.cbc.ca/radio/asithappens/as-it-happens-thursday-edition1.4466385/harvard-undergrad-cracks-code-of-knotted-inca-rope-used-as-an-ancient-excelspreadsheet-1.4466388

Chesterman J \& Galligan B (1997) Citizens without Rights: Aborigines and Australian Citizenship. Cambridge: Cambridge University Press.

Crooks K, Carlson S \& Dalton C (2019) Defining, controlling and analysing Indigenous data: Commitment to historical consistency or commitment to Australian Aboriginal and Torres Strait Islander peoples? Public Health Research \& Practice 29(4): e2941926. https://doi.org/10.17061/phrp2941926 
Department of Parliamentary Library (2003) Defining Aboriginality in Australia. https://www.aph.gov.au/about parliament/parliamentary departments/parliamentary library/ publications archive/cib/cib0203/03cib10

First Nations Information Governance Centre (2014) The First Nations Principles of OCAP. The First Nations Information Governance Centre. https://fnigc.ca/ocap-training/

Garroutte E (2003) Real Indians: Identity and the Survival of Native America. University of California Press. Heiss A (ed.) (2018). Growing Up Aboriginal in Australia. Melbourne: Black Inc.

Hemming S, Rigney D, Bignall S, Berg S, \& Rigney G (2019) Indigenous nation building for environmental futures: Murrundi flows through Ngarrindjeri country. Australasian Journal of Environmental Management 26(3): 216-235. https://doi.org/10.1080/14486563.2019.1651227

Jelfs P (2016) The Australian Bureau of Statistics' Aboriginal and Torres Strait Islander enumeration and engagement strategies: Challenges and future options. In Kukutai T \& Taylor J (eds.) Indigenous Data Sovereignty: Toward an Agenda. Canberra: ANU Press; 275-290. http://doi.org/10.22459/CAEPR38.11.2016

Kukutai T \& Cormack D (2020) "Pushing the space": Data sovereignty and self-determination in Aotearoa NZ. In Walter M, Kukutai T, Russo Carroll S, \& Rodriguez-Lonebear D (eds.) Indigenous Data Sovereignty and Policy. London: Routledge; pp. 21-35. https://doi.org/10.4324/9780429273957

Kukutai T \& Taylor J (2012) Postcolonial profiling of Indigenous populations. Limitations and responses in Australia and New Zealand. Espace Populations Sociétés 2012/1: 13-27. https://doi.org/10.4000/eps.4812

Kukutai T \& Taylor J (eds.) (2016) Indigenous Data Sovereignty: Toward an Agenda. Canberra: ANU Press. http://doi.org/10.22459/CAEPR38.11.2016

Kukutai T (2011) Building ethnic boundaries in New Zealand: representations of Maori identity in the census. In Axelsson P \& Skold P (eds.) Indigenous Peoples and Demography: The Complex Relation between Identity and Statistics. New York: Bergahn Books; pp. 33-54.

Kukutai, T., \& Walter, M. (2015). Recognition and indigenizing official statistics: Reflections from Aotearoa New Zealand and Australia. Statistical Journal of the IAOS 31(2): 317-326. https://doi.org/10.3233/sji-150896

Love v Commonwealth of Australia, B43/2018 B64/2018 (High Court of Australia February 11, 2020). http://eresources.hcourt.gov.au/showCase/2020/HCA/3

Lovett R (2016) Aboriginal and Torres Strait Islander community wellbeing: Identified needs for statistical capacity. Kukutai T \& Taylor J (eds.) Indigenous Data Sovereignty: Toward an Agenda. Canberra: ANU Press; pp. 213-231. http://doi.org/10.22459/CAEPR38.11.2016

Lovett R, Jones R, \& Maher B (2020) The Interception of Indigenous Data Sovereignty and Closing the Gap Policy in Australia. In Walter M, Kukutai T, Russo Carroll S, \& Rodriguez-Lonebear D (eds.) Indigenous Data Sovereignty and Policy. London: Routledge; pp. 36-51. https://doi.org/10.4324/9780429273957

Maiam nayri Wingara \& Australian Indigenous Governance Institute (2018) Indigenous Data Sovereignty Communique. Indigenous Data Sovereignty Summit, Canberra, ACT. https://www.aigi.com.au/resource/indigenous-data-sovereignty-communique/

Markham F \& Biddle N (2018) Recent changes to the Indigenous population geography of Australia: Evidence from the 2016 Census. Australian Population Studies 2(1): 1-13. https://doi.org/10.37970/aps.v2i1.21

Martin K \& Mirraboopa B (2003) Ways of knowing, being and doing: a theoretical framework and methods for indigenous and indigenist re-search: Journal of Australian Studies 27(76): 203-214. https://doi.org/10.1080/14443050309387838 
Mullane-Ronaki M-T T K K (2017) Indigenising the National Census? A Global Study of the Enumeration of Indigenous Peoples, 1985-2014. Master of Social Sciences thesis. University of Waikato, Hamilton, New Zealand. https://hdl.handle.net/10289/11175

Peters M A \& Mika C T (2017) Aborigine, Indian, indigenous or first nations? Educational Philosophy and Theory 49(13): 1229-1234. https://doi.org/10.1080/00131857.2017.1279879

Pool I (2016) Colonialism's and postcolonialism's fellow traveller: The collection, use and misuse of data on indigenous people. In Kukutai T \& Taylor J (eds.) Indigenous Data Sovereignty: Toward an Agenda. Canberra: ANU Press; pp. 57-76. http://doi.org/10.22459/CAEPR38.11.2016

Rowse T \& Smith L (2010) The Limits of 'Elimination' in the Politics of Population. Australian Historical Studies 41(1): 90-106. https://doi.org/10.1080/10314610903317598

Smith L T (2012) Decolonizing Methodologies: Research and Indigenous Peoples. London: Zed Books.

Statistics New Zealand (2018) 2018 Census: Design of forms. https://secure.livechatinc.com/

Statistics New Zealand (2021) 2021 Mana Ōrite Relationship Agreement. https://www.stats.govt.nz/about-us/what-we-do/mana-orite-relationship-agreement/

Sutton P (2003) Families of polity. In Sutton P (eds.) Native Title in Australia: An Ethnographic Perspective. Cambridge: Cambridge University Press; 206-231. https://doi.org/10.1017/CBO9780511481635.009

Taylor J \& Biddle N (2010) Estimating the Accuracy of Geographic Variation in Indigenous Population Counts. Australian Geographer 41(4): 469 484. https://doi.org/10.1080/00049182.2010.519695

Taylor J (2009) Indigenous demography and public policy in Australia: Population or peoples? Journal of Population Research 26(2): 115-130. https://doi.org/10.1007/s12546-009-9010-9

Taylor J (2011) Postcolonial transformation of the Australian Indigenous population. Geographical Research 49(3): 286-300.

Taylor J, Doran B, Parriman M \& Yu E (2014) Statistics for Community Governance: The Yawuru Indigenous Population Survey, Western Australia. International Indigenous Policy Journal 5(2): article 2. https://doi.org/10.18584/iipj.2014.5.2.2

United Kingdom House of Commons. (1900). Commonwealth of Australia Constitution Act 1900. https://www.legislation.gov.uk/ukpga/Vict/63-64/12/enacted

US Census Bureau (2020) Questions Asked on the Form. 2020Census.Gov. https://www.census.gov/programs-surveys/decennial-census/technicaldocumentation/questionnaires.2020 Census.html

Veracini L (2011) Introducing settler colonial studies. Settler Colonial Studies 1(1): 1-12. https://doi.org/10.1080/2201473X.2011.10648799

Walter M (2010) The politics of the data: how the Australian Statistical Indigene is constructed. International Journal of Critical Indigenous Studies 3(2): 45-56. https://doi.org/10.5204/ijcis.v3i2.51

Walter M (2016) Data politics and Indigenous representation in Australian statistics. In Kukutai T \& Taylor $\mathrm{J}$ (eds.) Indigenous Data Sovereignty: Toward an Agenda. Canberra: ANU Press; 79-97. http://doi.org/10.22459/CAEPR38.11.2016

Walter M (2018) The voice of Indigenous data. Griffith Review 60: 256-263. https://www.griffithreview.com/articles/voice-indigenous-data-beyond-disadvantage/

Walter M, Kukutai T, Russo Carroll S, \& Rodriguez-Lonebear D (eds.) (2020) Indigenous Data Sovereignty and Policy. London: Routledge. https://doi.org/10.4324/9780429273957

Whittaker A (2017) White Law, Blak Arbiters, Grey Legal Subjects: Deep Colonisation's Role and Impact in Defining Aboriginality at Law. Australian Indigenous Law Review 20(1): 4-47.

Wolfe P (1999) Settler Colonialism and the Transformation of Anthropology. London: Cassell. 
Yap M \& Yu E (2016) Data Sovereignty for the Yawuru in Western Australia. In Kukutai T \& Taylor J (eds.) Indigenous Data Sovereignty: Toward an Agenda. Canberra: ANU Press; pp. 233-261. http://doi.org/10.22459/CAEPR38.11.2016

Yu P (2012) The power of data in Aboriginal hands. CAEPR Topical issue No. 4/2012. Centre for Aboriginal Economic Policy Research, Australian National University. https://caepr.cass.anu.edu.au/research/publications/power-data-aboriginal-hands 